\title{
Isolation and Characterization of Rhodococcus spp. from Pistachio and Almond Rootstocks and Trees in Tunisia
}

\author{
Sabrine Dhaouadi ${ }^{1, *}+{ }^{(D}$, Amira Mougou Hamdane ${ }^{1,+}$ and Ali Rhouma ${ }^{2}$ \\ 1 Laboratory of Bio Aggressors and Integrated Pest Management, Department of Plant Health \\ and Environment, National Institute of Agronomy, University of Carthage, Tunis 1082, Tunisia; \\ amiramougou@gmail.com \\ 2 Olive Tree Institute, Improvement and Protection of Olive Genetic Resources BP 208 Mahrajene City, \\ Tunis 1082, Tunisia; ali.rouma@gmail.com \\ * Correspondence: sabrinedhaouadi@outlook.com; Tel.: +216-2282-4837 \\ + Both authors contributed equally to this work.
}

Citation: Dhaouadi, S.; Hamdane, A.M.; Rhouma, A. Isolation and Characterization of Rhodococcus spp. from Pistachio and Almond Rootstocks and Trees in Tunisia. Agronomy 2021, 11, 355. https:// doi.org/10.3390/agronomy11020355

Academic Editor: Renaud Travadon

Received: 18 January 2021

Accepted: 13 February 2021

Published: 17 February 2021

Publisher's Note: MDPI stays neutral with regard to jurisdictional claims in published maps and institutional affiliations.

Copyright: (c) 2021 by the authors. Licensee MDPI, Basel, Switzerland. This article is an open access article distributed under the terms and conditions of the Creative Commons Attribution (CC BY) license (https:// creativecommons.org/licenses/by/ $4.0 /)$
Abstract: The purpose of this study was to isolate and identify Rhodococcus spp. strains from almond and pistachio rootstocks and trees in Tunisia. Twenty-eight strains were identified through $16 \mathrm{~S}$ rDNA and vicA genes amplification and sequencing. Pea bioassay was performed to determine the pathogenicity of the strains. Representative $16 \mathrm{~S}$ rDNA and vicA sequences of eight strains from pistachio and seven strains from almond were closely related ( $>98 \%$ similarity) to Rhodococcus spp. accessions in GenBank. Phylogenetic analysis based on 16S rDNA sequences revealed that the yellowcolored strains clustered with phytopathogenic Rhodococcus fascians. The red and orange-colored strains were separated into a different group with $R$. kroppenstedtii and $R$. corynebacteiroides isolates. Eleven strains affected the pea seedlings' growth and exhibited different levels of virulence. The number of shoots was significantly higher in seedlings inoculated with four Rhodococcus strains, whereas the other three strains caused up to $80 \%$ of plant height reduction and reduced root secondary growth compared to non-inoculated pea seedlings. These strains, most of which are epiphytes from asymptomatic hosts, showed strong pathogenicity during pea bioassay and were established endophytically in pea tissues. Ten att and five fas genes were detected in four strains and may represent a novel model of plant pathogenic Rhodococcus virulence. The results of our survey showed that Rhodococcus is present but not prevalent in all visited orchards of almond and pistachio rootstocks and trees. Our surveys complemented the investments being made on ornamental species in Tunisia and unveiled the presence of undocumented plant-associated Rhodococcus spp. on economically important crops.

Keywords: Rhodococcus; epiphyte; inoculation; endophyte; pathogenicity; virulence genes

\section{Introduction}

Members of the genus Rhodococcus are Gram-positive bacteria, most of which are benign, and they have been frequently found in hydrocarbon-contaminated soils and from extreme environments [1-5]. Several plant-associated Rhodococcus spp. isolates have been found in the rhizophere [6], phyllosphere [7], and endosphere of plants [8-10], most of which are plant growth-promoters during the epiphytic stage [11-14], and others acquiring virulence factors can cause disease [15-17].

However, despite the association of several Rhodococcus isolates with plants, Rhodococcus fascians remains the only well-described plant pathogenic species $[15,18,19]$. $R$. fascians causes leafy galls [20-23] through the secretion and modulation of cytokinin pathways strictly encoded by genes of the fas operon located on the linear plasmid pFiD188 [24-30]. FasR, an AraC type regulatory gene [31], fas A gene coding for a P450 monooxygenase [25], and fasD, an isopentenyl transferase [32], are confirmed to be necessary for pathogenesis of the leafy gall $R$. fascians inducer $[15-17,33]$. The ability of $R$. fascians to cause disease has 
been found to be dependent on another locus of the pFiD188, the att locus that is essential for full virulence through the production of an autoregulatory compound [32,34]. In this locus, the presence of virulent and avirulent strains of $R$. fascians has been tested by the detection of the att $\mathrm{A}$, att $\mathrm{B}$, and att $\mathrm{R}$ virulence genes [15-17,35].

New plant species have been identified as hosts of the plant pathogenic $R$. fascians and other newly reported members of the genus Rhodococcus [33,36-40]. Two Rhodococcus isolates designated as PBTS1 and PBTS2, one of which is a $R$. fascians, have resulted in a significant loss to the US pistachio industry [36,37]. Rhodococcus PBTS isolates have shown a synergistic relationship altering plant development of UCB-1 pistachio rootstocks $[33,37]$ and recently of tobacco sp. [33]. However, the pathogenic strategies deployed by these isolates are yet unknown and appear to be different from the leafy gall inducers $[18,33]$. Similar to PBTS, two new plant diseases in Tunisia caused by unique isolates of Rhodococcus spp. have been documented on ornamental plants originating in tissue culture [38,39]. The discovery of these two new pathosystems further demonstrates the risk of clonal plants to formerly undocumented isolates of Rhodococcus.

Pistachio (Pistacia vera L.) and almond (Prunus amygdalus Batsch) nut crops are considered among the most profitable nut crops production in the world [41], and they continue to increase every year in acreage and yield throughout the world [42]. Pistachio and almond production in Tunisia is very low and shares only $1 \%$ of the world production [42]. Currently, more than 250,000 and 30,000 ha are planted with almond and pistachio trees in Tunisia, respectively [43]. The production of these crops is based on the use of locally adapted clones generally located in the arid and semi-arid central and southern areas [43-45]. The production of pistachio is based majorly on one local pistachio cultivar "Mateur" that is either grafted on P. vera or P. atlantica rootstocks [46], whereas the almond production is based on diversified local cultivars propagated onto rootstocks of a number of interspecific hybrids including Garnem (peach hybrid: 'Garfi' x 'Nemared'), bitter almond (Prunus amygdalus var. amara), and GF677 (Prunus hybrid: P. amygdalus $x$ P. persica) $[43,45]$. Despite the large cultivated area and the favorable warm region in Tunisia, the low genetic diversity of cultivars and rootstocks and traditional cultural practices are leading to sensitivity of almond and pistachio trees to both biotic and abiotic stresses $[43,46]$. Moreover, pests and diseases are considered as serious problems for nut crop production in the temperate zones and the Mediterranean regions, resulting in yield reduction and poor quality of the fruit [47-50].

The epidemiological background on the transmission and survival of plant pathogenic Rhodococcus spp. on nut crops [51] combined with disease emergence in propagation facilities and orchards urged the investigation of the risk to nut tree production in Tunisia. Since the prevalence of Rhodococcus spp. on permanent crops in Tunisia is unknown, the goal of this study was to determine whether Rhodococcus spp. are common or perhaps even ubiquitous epiphytes or endophytes of almond and pistachio, especially those propagated with ornamental plant species.

\section{Materials and Methods}

\subsection{Surveys, Sites of Prospection and Sampling}

During 2018 and 2019, many regions of the main pistachio and almond-producing areas in Tunisia were surveyed for the presence of Rhodococcus spp. Surveys were conducted visiting 30 orchards and 19 commercial nurseries located in Gafsa, Kasserine, Sidi-Bouzid, Manouba, Tunis, Kef, and Bizerte governorates. Investigated species and varieties of almond included bitter almond (Prunus dulcis), Garnem (Prunus persica $\times$ Prunus amygdalus), GF-677 (Prunus persica x Prunus amygdalus), 'Mazetto' green almonds (Prunus amygdalus), and Lauranne (Prunus amygdalus). Investigated pistachio species included majorly the Pistacia vera cv. 'Mateur' widely used as a rootstock and scion, and the pistachio rootstock Pistacia atlantica. Other pistachio scion varieties including 'Kerman', 'Meknassy', 'Ohadi', 'Safeed', 'Red Aleppo', 'Thyna 1', 'Thyna 2', 'Nouri', 'Lybie rouge', 'Achouri', 'Amri', 'Razzai', and 'Jebari' grown in the research station in Sfax governorate were also examined. 
Ten pistachio and ten almond rootstocks were excavated with roots intact from each nursery. From each rootstock tree, ten leaves, ten stem segments $(5 \times 5 \mathrm{~mm}$ each), and ten root segments $(1 \mathrm{~cm}$ each) were sampled for epiphytic and endophytic isolations. Twenty trees were randomly selected per orchard, and twenty leaves per tree were sampled for the determination of epiphytic and endophytic populations of Rhodococcus spp. We collected a bulk sample from asymptomatic trees and individual samples from symptomatic trees.

\subsection{Bacterial Isolation and Growth Conditions}

To detect epiphytic populations of Rhodococcus spp., 10 leaves from each sample were incubated in $50 \mathrm{~mL}$ of $1 \mathrm{X}$ sterile phosphate-buffered saline (PBS) $(137 \mathrm{mM} \mathrm{NaCl}$, $\left.2.7 \mathrm{mM} \mathrm{KCL}, 10 \mathrm{mM} \mathrm{Na}_{2} \mathrm{HPO}_{4}, 1.8 \mathrm{mM} \mathrm{KH}_{2} \mathrm{PO}_{4} ; \mathrm{pH} 7,4\right)$. Ten stem fragments $(1 \mathrm{~cm}$ each) were cut from each rootstock and incubated in $20 \mathrm{~mL}$ of sterile PBS buffer. Ten root segments $(5 \mathrm{~cm}$ each) were excised from the rootstock tree, briefly washed under running tap water, and then incubated in $20 \mathrm{~mL}$ of sterile PBS buffer. All plant tissue samples incubated in the PBS buffer were placed on a rotary agitator for $30 \mathrm{~min}$ at room temperature with gentle shaking. The resulting suspensions were serially diluted up to $10^{-7}$ and $200 \mu \mathrm{L}$ of each dilution of $10^{-5}$ through $10^{-7}$ were plated onto D2 medium, which is a semi-selective medium for Gram-positive Corynebacterium [52] (Kado and Heskett $1970)$ amended with cycloheximide $(2 \%)$ and pimaricin $\left(4.0 \mathrm{mg} \mathrm{L}^{-1}\right)[38,39]$. To detect endophytic populations of Rhodococcus spp., the same plant tissues used for epiphytic isolation were surface disinfected as described in [38,39] and macerated in sterile distilled water (SDW). The resulting macerated plant tissues were assessed for serial dilutions and plating as described above. Isolation plates were incubated in the dark at $27^{\circ} \mathrm{C}$ for 4 to 15 days for the detection of epi- and endophytic populations, respectively.

\subsection{Identification of Bacterial Isolates and Virulence Detection}

Bacterial colonies with colors ranging from cadmium yellow and deep chrome yellow to deep orange were selected for further analysis. Bacterial cultures were re-streaked onto D2 medium for single pure colonies, incubated for 2 days at $27^{\circ} \mathrm{C}$, and used for genomic DNA extraction and molecular characterization. DNA extraction was performed following the protocol used by innuPREP Bacteria DNA extraction Kit (Analytic Jena AG, Germany). Then, genomic DNA was visualized on 1,5\% agarose gel stained with ethidium bromide and photographed on a UV-transilluminator. DNA concentration $\left(n g \mu \mathrm{L}^{-1}\right)$ was also determined using a spectrophotometer (Maestro Nano GEN MN-913) for better PCR optimization. All DNA samples were stored in TE buffer $\left(10 \mathrm{mmoL} \mathrm{L}^{-1}\right.$ Tris, $\mathrm{pH} 8$, $1 \mathrm{mmoL} \mathrm{L}{ }^{-1}$ EDTA) at $-20^{\circ} \mathrm{C}$ until analyzed.

Amplifications and sequencing of the $16 \mathrm{~S}$ rDNA gene and the specific chromosomal $R$. fascians vicA gene $[35,53,54]$ were used to identify the bacterial isolates as indicated in Table 1. 
Table 1. Primers nucleotide and PCR mix, cycling time, and conditions used in this study.

\begin{tabular}{|c|c|c|c|c|c|c|}
\hline Primer & Nucleotide Sequence $\left(5^{\prime} \rightarrow 3^{\prime}\right)$ & Target & $\begin{array}{l}\text { Amplicon } \\
\text { Size (bp) }\end{array}$ & Reference & Cycling Conditions & $\begin{array}{l}\text { Total Amount } \\
(25 \mu \mathrm{L} / \mathrm{PCR})\end{array}$ \\
\hline $\begin{array}{c}27 \mathrm{~F} \\
1492 \mathrm{R}\end{array}$ & $\begin{array}{l}\text { AGAGTTTGATCMTGGCTCAG } \\
\text { TACGGYTACCTTGTTACGACTT }\end{array}$ & $16 \mathrm{~S}$ ribosomal DNA & 1500 & [53] & $\begin{array}{l}1 \text { cycle of initial denaturation: at } 95^{\circ} \mathrm{C} \text { for } \\
5 \mathrm{~min} ; 35 \text { cycles of } \\
\text { denaturation at } 95^{\circ} \mathrm{C} \text { for } 30 \mathrm{~s} \text {, annealing at } \\
59^{\circ} \mathrm{C} \text { for } 30 \mathrm{~s} \text {, and extension at } 72{ }^{\circ} \mathrm{C} \text { for } 90 \mathrm{~s} \text {; } \\
1 \text { cycle of final extension at } 72{ }^{\circ} \mathrm{C} \text { for } 5 \text { min }\end{array}$ & $\begin{array}{c}50 \text { ng: DNA } \\
\text { 1X: Taq buffer } \\
0.2 \mathrm{mM}: \mathrm{dNTPs} \\
4 \mathrm{mM}: \mathrm{MgCl}_{2} \\
\text { 24 pmol: each primer } \\
\text { 1U: Taq DNA polymerase }\end{array}$ \\
\hline vicA1497FvicA1990R & $\begin{array}{l}\text { TCTGGATCTCGAAGTGCAAACCGT } \\
\text { AGCGTACAAGGCCTTCCTGAAAGA }\end{array}$ & $\begin{array}{l}\text { Putative malate } \\
\text { synthase }\end{array}$ & 179 & {$[54]$} & $\begin{array}{l}1 \text { cycle of initial denaturation: at } 95^{\circ} \mathrm{C} \text { for } \\
\qquad 5 \mathrm{~min} ; 45 \text { cycles of } \\
\text { denaturation at } 95^{\circ} \mathrm{C} \text { for } 30 \mathrm{~s} \text {, annealing at } \\
64^{\circ} \mathrm{C} \text { for } 30 \mathrm{~s} \text {, and extension at } 72{ }^{\circ} \mathrm{C} \text { for } 90 \mathrm{~s} \text {; } \\
1 \text { cycle of final extension at } 72{ }^{\circ} \mathrm{C} \text { for } 5 \text { min }\end{array}$ & $\begin{array}{c}50 \mathrm{ng}: \text { DNA } \\
\text { 1X: Taq buffer } \\
0.24 \mathrm{mM}: \mathrm{dNTP} \\
2 \mathrm{mM}: \mathrm{MgCl}_{2} \\
\text { 10 pmol: each primer } \\
\text { 1U: Taq DNA polymerase }\end{array}$ \\
\hline $\begin{array}{l}\text { JPEL } \\
\text { JPER }\end{array}$ & $\begin{array}{l}\text { GGGAATTCCGACCGTATCCAGTGT } \\
\text { CGGGATCCATATCGAACCGCCCTC }\end{array}$ & $\begin{array}{l}\text { fas }-1 \text { isopentenyl- } \\
\text { transferase }\end{array}$ & 225 & [55] & $\begin{array}{l}1 \text { cycle of initial denaturation: at } 94{ }^{\circ} \mathrm{C} \text { for } \\
\qquad 3 \mathrm{~min} ; 33 \text { cycles of } \\
\text { denaturation at } 94{ }^{\circ} \mathrm{C} \text { for } 30 \mathrm{~s} \text {, annealing at } \\
65^{\circ} \mathrm{C} \text { for } 60 \mathrm{~s} \text {, and extension at } 72{ }^{\circ} \mathrm{C} \text { for } 40 \mathrm{~s} \text {; } \\
1 \text { cycle of final extension at } 72{ }^{\circ} \mathrm{C} \text { for } 5 \text { min }\end{array}$ & $\begin{array}{c}10 \mathrm{ng}: \text { DNA } \\
1 \mathrm{X}: \text { Taq buffer } \\
0.4 \mathrm{mM}: \mathrm{dNTPs} \\
4 \mathrm{mM}: \mathrm{MgCl}_{2} \\
\text { 10 pmol: each primer } \\
\text { 1U: Taq DNA polymerase }\end{array}$ \\
\hline $\begin{array}{l}\mathrm{p} 450-\mathrm{F} \\
\mathrm{p} 450-\mathrm{R}\end{array}$ & $\begin{array}{l}\text { TATCCTTGCTGCGGAGTTCT } \\
\text { CAACCACCGCAATAATTCCT }\end{array}$ & $\begin{array}{c}\text { fasA, } \mathrm{P} 450 \\
\text { monooxygenase }\end{array}$ & 538 & \multirow{2}{*}{ [56] } & \multirow{3}{*}{$\begin{array}{l}1 \text { cycle of initial denaturation: at } 94{ }^{\circ} \mathrm{C} \text { for } \\
22 \mathrm{~min} ; 33 \text { cycles of } \\
\text { denaturation at } 94{ }^{\circ} \mathrm{C} \text { for } 30 \mathrm{~s} \text {, annealing at } \\
55^{\circ} \mathrm{C} \text { for } 30 \mathrm{~s} \text {, and extension at } 72{ }^{\circ} \mathrm{C} \text { for } 60 \mathrm{~s} \text {; } \\
1 \text { cycle of final extension at } 72{ }^{\circ} \mathrm{C} \text { for } 5 \text { min }\end{array}$} & \multirow{3}{*}{$\begin{array}{c}50 \text { ng: DNA } \\
\text { 1X: Taq buffer, } \\
1.5 \mathrm{mM}: \mathrm{MgCl}_{2} \\
0.2 \mathrm{mM} \text { dNTPs, } \\
\text { 10 pmol: each primer, } \\
\text { 1U: Taq DNA polymerase }\end{array}$} \\
\hline $\begin{array}{l}\text { Fas }-\mathrm{F} \\
\text { Fas }-\mathrm{R}\end{array}$ & $\begin{array}{l}\text { CAACACTACTTTGCCCAGCA } \\
\text { GGCCAACTCCTCTGGTGTTA }\end{array}$ & $\begin{array}{c}f a s \mathrm{D}, \\
\text { isopentenyltransferase }\end{array}$ & 195 & & & \\
\hline $\begin{array}{l}\text { fasR F } \\
\text { fasR R }\end{array}$ & $\begin{array}{l}\text { ATCAACGTCGACCTCGGAAT } \\
\text { GCACGGGTTACAGTCATT }\end{array}$ & $\begin{array}{l}\text { fasR gene, putative } \\
\text { transcriptional } \\
\text { regulator }\end{array}$ & 688 & [31] & & \\
\hline $\begin{array}{l}\text { attA }-585 \mathrm{~F} \\
\text { attA-879R }\end{array}$ & $\begin{array}{l}\text { GCCTGGAAGCGCATCAACATCAAT } \\
\text { TTCTTCTGCGGCATGATCGAGCTA }\end{array}$ & $\begin{array}{c}\text { attA, } \\
\text { Arginino-succinate } \\
\text { lyase }\end{array}$ & 505 & \multirow[t]{2}{*}{ [35] } & \multirow{2}{*}{$\begin{array}{l}1 \text { cycle of initial denaturation: at } 95^{\circ} \mathrm{C} \text { for } \\
22 \mathrm{~min} ; 35 \text { cycles of } \\
\text { denaturation at } 95^{\circ} \mathrm{C} \text { for } 20 \mathrm{~s} \text {, annealing at } \\
55^{\circ} \mathrm{C} \text { for } 20 \mathrm{~s} \text {, and extension at } 72^{\circ} \mathrm{C} \text { for } 60 \mathrm{~s} \text {; } \\
1 \text { cycle of final extension at } 72{ }^{\circ} \mathrm{C} \text { for } 5 \mathrm{~min}\end{array}$} & \multirow{2}{*}{$\begin{array}{l}10 \mathrm{ng}: \text { DNA } \\
\text { 1X: Taq buffer } \\
\text { 0.2mM: } \mathrm{dNTPs} \\
2 \mathrm{mM}: \mathrm{MgCl}_{2} \\
\text { 10pmol: each primer } \\
\text { 1U: Taq DNA polymerase }\end{array}$} \\
\hline $\begin{array}{l}\text { attR-683F } \\
\text { attR-887R }\end{array}$ & $\begin{array}{l}\text { GGTGCAGCAGTATTCGTTGTCGTT } \\
\text { TGCACATCTCGTCTTCTGCAGTCA }\end{array}$ & $\begin{array}{l}\text { att } \mathrm{R}, \text { LysR type } \\
\text { transcriptional } \\
\text { regulator }\end{array}$ & 320 & & & \\
\hline
\end{tabular}


The detection of virulent Rhodococcus strains was performed targeting plasmid-borne virulence genes of the fas and att loci using published primers (Table 1) [34,35,54-56]. PCR cycling conditions of each specific gene, including fas $\mathrm{A}, f a s \mathrm{D}$, att $\mathrm{A}$, and att $\mathrm{R}$ genes were optimized by varying the annealing temperature, $\mathrm{dNTPs}$, and $\mathrm{MgCl}_{2}$ concentrations and the amount of DNA template. Primer sequences and PCR amplification conditions are given in Table 1. All PCR amplifications were performed with the Thermo Cycler 2720 (Applied Biosystems, Foster City, CA, USA, Thermo Fisher Scientific, Waltham, MA, USA) according to the protocols presented in Table 1.

The detection of fas and att genes was also determined from the whole genome sequences of three Rhodococcus strains. The selection of these three Rhodococcus strains, identified as R. fascians GS6, R. fascians SB10, and R. kroppenstedtii K5 [40,57], was based on their high pathogenicity effect during pea bioassay (this study). Each virulence gene from pFiD188 plasmid (GenBank accession number JN093097) was used to identify homologs of genes on GS6, SB10, and K5 genomes. The translated sequences of attA, attR, fasR, fasA, and fas D were used in BLAST searches against the NCBI nr database to identify homologous sequences. Sequences from pFiD188 (pFi_001-pFi_184) and 4804 protein sequences of the chromosome of D188 (NCBI Reference Sequence: NZ_CP015235.1) were downloaded and used as queries in searches against GS6, SB10, and K5 genome assemblies. Protein database searches were performed using compositionally adjusted substitution matrices [58] and Gapped BLAST and PSI-BLAST programs [59].

\subsection{Multilocus Analysis}

Nearest-neighbor phylogenetic trees based on 16S rDNA and vicA gene sequences were constructed using MEGA software version 6.06 [60]. Chromatograms of DNA sequences were analyzed using Chromas trace software version 2.6.6 (Technelysium, Pty Ltd., Brisbane, Australia). Publicly available $16 \mathrm{~S}$ rDNA and vicA sequences of plant-associated and environmental type strains of Rhodococcus were collected from the NCBI database. Sequence reads were assembled in MEGA6 and aligned using the ClustalW algorithm. Phylogenetic trees were constructed using Tamura-Nei models [61] for neighbor-joining maximum likelihood with 1000 bootstrap replicates [62] and a support threshold of 70\%.

\subsection{Pathogenicity on Pisum Satioum}

\subsubsection{Bacterial Strains}

Pure cultures of Rhodococcus strains were grown on D2 medium for 2 days at $27^{\circ} \mathrm{C}$. Each Rhodococcus strain was inoculated in a 100-mL Erlenmeyer flask containing $40 \mathrm{~mL}$ of nutrient broth (NB) and incubated for 2 days at room temperature $\left(25\right.$ to $\left.28{ }^{\circ} \mathrm{C}\right)$ with shaking at $200 \mathrm{rpm}$ [63]. After two overnights, the culture was transferred to 50-mL centrifuge tubes and centrifuged for $15 \mathrm{~min}$ at $15^{\circ} \mathrm{C}$ and $3000 \times g$ [63]. The supernatant was discarded, and the pellets were resuspended in SDW [63]. Then, the cell suspensions were pooled and diluted to an Optical Density (OD) at $600 \mathrm{~nm}$ of 0.18 (advanced microprocessor UV/VIS Spectrometer, single beam Li-295, Lasany, MA, USA) in SDW, corresponding to approximately $2.5 \times 10^{7} \mathrm{CFU} \mathrm{mL}^{-1}$ [35]. Bacterial suspension was kept at $4^{\circ} \mathrm{C}$ for a subsequent use within $2 \mathrm{~h}$.

\subsubsection{Pea Bioassay}

Following the protocol described by [35], Pisum sativum var 'Lincoln' seeds were surface disinfected briefly in $70 \%$ ethanol and rinsed in $10 \%$ sodium hypochlorite for $10 \mathrm{~min}$ and washed three to four times in SDW. Following disinfection, seeds were soaked in SDW for one hour and then placed on $1.5 \%$ water agar for 4 days at $20^{\circ} \mathrm{C}$ until germination. Once the radicals emerged, seedlings were soaked in $20 \mathrm{~mL}$ of each Rhodococccus suspension for $2 \mathrm{~h}$ and then placed in tubes containing Hoagland's medium. Control pea seedlings were soaked in sterile Hoagland's solution. Ten seedlings were used per treatment, and the bioassay was repeated twice. Inoculated pea seedlings were placed in a growth chamber with a $12-\mathrm{h}$ photoperiod at $18^{\circ} \mathrm{C}$ for two weeks. The main stem length and the number of 
lateral shoots at the cotyledon node of each pea seedling were measured at 14 days post inoculation (dpi). The degree of virulence was based the on the percentage of pea seedlings showing stunting and fasciations as well as the presence of the fas virulence genes.

\subsubsection{Re-Isolation of the Pathogen}

Epiphytic and endophytic Rhodococcus strains were re-isolated from inoculated and uninoculated pea seedlings at $14 \mathrm{dpi}$, and the presence of the vicA and fas genes among these populations was determined by PCR amplification. Three symptomatic and three asymptomatic pea seedlings from each treatment were used for epiphytic and endophytic pathogen re-isolation. The aerial part of the inoculated pea seedling, including galls and lateral shoots, was separated from the roots and suspended in $20 \mathrm{~mL}$ of sterile PBS buffer and incubated for $20 \mathrm{~min}$ with gentle shaking. Serial dilutions up to $10^{-10}$ were determined and $200 \mu \mathrm{L}$ from each of $10^{-8}$ to $10^{-10}$ dilutions was streaked onto D2 medium. For endophytic isolation of Rhodococcus strains, the same tissue sample was briefly surface disinfected in $70 \%$ of ethanol and then in $10 \%$ of sodium hypochlorite for $30 \mathrm{~s}$ and rinsed four times in SDW [35]. The surface-disinfected aerial part of the pea seedling was macerated with a sterile mortar in sterile PBS buffer. The resulting suspension was serially diluted to $10^{-10}$, and $200 \mu \mathrm{L}$ from each of the $10^{-8}$ to $10^{-10}$ dilutions was streaked onto D2 medium. Bacterial colonies were streaked onto D2 medium for purification, genomic DNA extraction, and PCR amplifications.

\subsection{Statistical Analysis}

The influence of inoculation treatments on stem length and lateral shoots of pea seedlings was determined with an analysis of variance (ANOVA) and means were separated using a Student-Newman-Keuls test (SAS 9.1; SAS Institute Inc., Cary, NC, USA).

\section{Results}

\subsection{Prospection and Sampling}

Among the 30 visited pistachio and almond orchards, two orchards growing pistachio trees in the governorates of Kef and Bizerte yielded Rhodococcus spp. isolates (Table 2). The pistachio trees in these orchards exhibited multiple pale shoots at the crown with small leaves (data not shown). Among the 19 visited commercial nurseries, one nursery producing fruit and nut rootstock trees located in Kasserine governorate had bitter almond rootstocks showing abnormal growth (data not shown). More than $80 \%$ of these rootstocks exhibited bushy phenotype, shoot proliferation, severe stunting, and compact growth due to reduced internodes length (data not shown). However, one endophytic Rhodococcus isolate was obtained from the unusual growth of bitter almond rootstocks. In the same aforementioned nursery, P. vera and almond 'GF' rootstock trees exhibited similar symptoms but did generate Rhodococcus spp. (data not shown). Asymptomatic almond rootstocks and pistachio trees grown in five different commercial nurseries and one orchard have been found to harbor Rhodococcus spp. isolates (Table 2). 
Table 2. Rhodococcus spp. isolates from pistachio and almond plants grown in a commercial nursery and orchard sources in different regions of Tunisia.

\begin{tabular}{|c|c|c|c|c|c|c|c|c|c|}
\hline Nursery/Orchard & Isolate Code & Location & Crop & $\begin{array}{l}\text { Rootstock/Scion } \\
\text { Cultivars }\end{array}$ & Symptomatic/Asymptomatic & Epi-/Endophytic & Isolate Color & $\begin{array}{c}\text { 16S rDNA } \\
\text { Gene GenBank } \\
\text { Accession } \\
\text { Number }\end{array}$ & $\begin{array}{c}\text { vicA Gene } \\
\text { GenBank } \\
\text { Accession } \\
\text { Number }\end{array}$ \\
\hline \multirow{8}{*}{ Nursery } & $\mathrm{JZ1}$ & \multirow{2}{*}{ Gafsa } & \multirow{2}{*}{ Almond } & Bitter almond & \multirow{2}{*}{ Asymptomatic } & Epiphyte & Yellow chrome & MN366362 & * \\
\hline & $\mathrm{JZ2}$ & & & GF & & Epiphyte & Yellow chrome & MN366363 & MN544259 \\
\hline & BA2 & \multirow{2}{*}{ Manouba } & \multirow{2}{*}{ Almond } & \multirow{2}{*}{ Mazetto/GF } & \multirow{2}{*}{ Asymptomatic } & Epiphyte & Red-orange & MN366364 & MN544260 \\
\hline & BA3 & & & & & Epiphyte & Yellow chrome & MN366365 & MN544261 \\
\hline & $\mathrm{F} 1$ & Tunis & Almond & GF & Asymptomatic & Epiphyte & Yellow chrome & MN366366 & MN544262 \\
\hline & GS6 & Kasserine & Almond & Bitter almond & Symptomatic & Endophyte & Yellow chrome & MK455765 & MN544263 \\
\hline & SB10 & Sidi Bouzid & Almond & Garnem & Asymptomatic & Endophyte & Yellow chrome & MK455764 & MN544264 \\
\hline & CS & Gafsa & Pistachio & P. vera var. Mateur & Asymptomatic & Epiphyte & Yellow chrome & MN366367 & * \\
\hline \multirow{7}{*}{ Orchard } & K4 & \multirow{2}{*}{ Kef } & \multirow{2}{*}{ Pistachio } & \multirow{2}{*}{ P. vera var. Mateur } & \multirow{2}{*}{ Symptomatic } & Epiphyte & Yellow chrome & MN366368 & MN544265 \\
\hline & K5 & & & & & Epiphyte & Red-orange & MK455766 & MN544266 \\
\hline & Mt1 & \multirow{5}{*}{ Bizerte } & \multirow{5}{*}{ Pistachio } & P. vera var. Mateur & Asymptomatic & Epiphyte & Yellow chrome & MN366369 & MN544267 \\
\hline & Mt2 & & & \multirow{2}{*}{ P. atlantica } & \multirow{2}{*}{ Symptomatic } & Epiphyte & Yellow chrome & MN366370 & MN544268 \\
\hline & Mt5 & & & & & Epiphyte & Red-orange & MN366371 & MN544269 \\
\hline & Mt9 & & & \multirow{2}{*}{ P. vera } & \multirow{2}{*}{ Symptomatic } & Epiphyte & Yellow chrome & MN366372 & MN544270 \\
\hline & Mt11 & & & & & Epiphyte & Red-orange & MN366373 & $*$ \\
\hline
\end{tabular}

*: Bad DNA sequence quality, not acceptable for GenBank accession submission. 


\subsection{Isolation and Identification of Bacterial Isolates}

Epiphytic and endophytic Rhodococcus spp. isolates were obtained from foliage of almond and pistachio rootstocks and trees (Table 2). Yellow and deep-orange pigmented, rough, and smooth bacterial colonies were observed 7 days post-incubation at $27{ }^{\circ} \mathrm{C}$ (Table 2). However, putative yellow-colored Rhodococcus colonies were the most abundant colonies over the orange ones (data not shown). In many pistachio and almond commercial nurseries and field orchards, yellow and orange-colored Rhodococcus isolates were isolated from the same leaf tissue (Table 2). Overall, most of the Rhodococcus strains were phylloplane of pistachio and almond leaves. No epiphytic or endophytic Rhodococcus strains were obtained from pistachio and almond roots or stems. Only two endophytic Rhodococcus strains were obtained from leaves of bitter almond and Garnem rootstocks propagated in the commercial nursery of Kasserine (Table 2). A total of 28 bacterial isolates were cultured for genomic DNA extraction and PCR amplification. Only fifteen isolates generated positive vicA amplicons and were therefore used for subsequent 16S rDNA gene identification. Based on sequence analysis of the $16 \mathrm{~S}$ rDNA and vicA genes, eight Rhodococcus strains were identified from pistachios and seven Rhodococcus strains were identified from almonds (Table 2). Representative 16S rDNA and vicA sequences of Rhodococcus strains were deposited into GenBank, and accessions numbers are presented in Table 2.

\subsection{Multilocus Analysis of Bacterial Strains}

Sequences of the 16S rDNA and vicA genes of the pistachio and almond Rhodococcus strains were highly similar (>98 \%) to Rhodococcus spp. accessions in GenBank (Figure 1A). Based on $16 \mathrm{~S}$ rDNA sequence analysis, the deep-orange-colored strains K5, Mt5, BA2, and Mt11 from pistachio and strain BA2 from almond were 100\% similar to Rhodococcus sp. hm1 (MT012181.1), Rhodococcus sp. NQS13 (MN822627.1), Rhodococcus sp. OS-11 (EF612310.1), and R. corynebacterioides cqsA3 (MN826595.1) isolates (Figure 1A).

Based on a 16S rDNA gene-based tree, K5, BA2, Mt5, and Mt11 strains formed a distinct phylogenetic lineage with other isolates, including Rhodococcus sp. strain B4 (MH685557), Rhodococcus sp. strain N2 (MN150688), Rhodococcus sp. PBTS1 (CP015219.1), R. kroppenstedtii DSM 44908 (NR_118599.1), R. enclensis NIO-1009 (NR_134154.1), and R. corynebacterioides strains DSM 20151 (NR_119107.1), and C2 (MG280772.1) (Figure 1A).

Analysis of the $16 \mathrm{~S}$ rDNA sequences of the yellow-colored strains from almond JZ1, JZ2, GS6, and SB10 were highly similar (99, 9 to $100 \%$ ) to phytopathogenic $R$. fascians D188 (CP015235.1) and Rhodococcus sp. PBTS2 (CP015220.1) (Figure 1A). Some yellowcolored strains including BA3, F1, K4, Mt1, and Mt9 were highly similar (99.9 to $100 \%$ ) to other strains of $R$. fascians (MK178494.1, MF620062.1, KY775507.1) and Rhodococcus spp. (MH725305.1, MT012184.1, MT012166.1) (Figure 1A). The remaining yellow-colored strains CS and Mt2 were highly similar to R. sovatensis a19 (MK726114) and R. cerastii (KY775508, KY775501), respectively (Figure 1A). The three almond strains JZ1, GS6, and SB10 formed a well distinct clade with phytopathogenic $R$. fascians D188 (CP015235.1) and R. fascians DSM 20669 (X79186.1) (Figure 1A).

Based on vicA sequence analysis, our almond and pistachio Rhodococcus strains were highly similar to Rhodococcus spp. isolates affecting pistachio trees in California (PBTS1 and PBTS2) and New Mexico (NM-J PBTS) and to R. fascians D188 (Figure 1B). However, in the vicA-based phylogenetic tree, two clades were generated; one supported our Rhodococcus almond and pistachio strains with Rhodococcus spp. associated with diseased ornamentals in Tunisia and pistachio in New Mexico (Figure 1B). The other clade supported environmental species and plant pathogenic of Rhodococcus including R. fascians D188, Rhodococcus PBTS1, and PBTS2 (Figure 1B). However, the yellow and deep-orange-colored strains were not classified separately in distinct clades as in the $16 \mathrm{~S}$ rDNA phylogenetic tree (Figure 1A). 


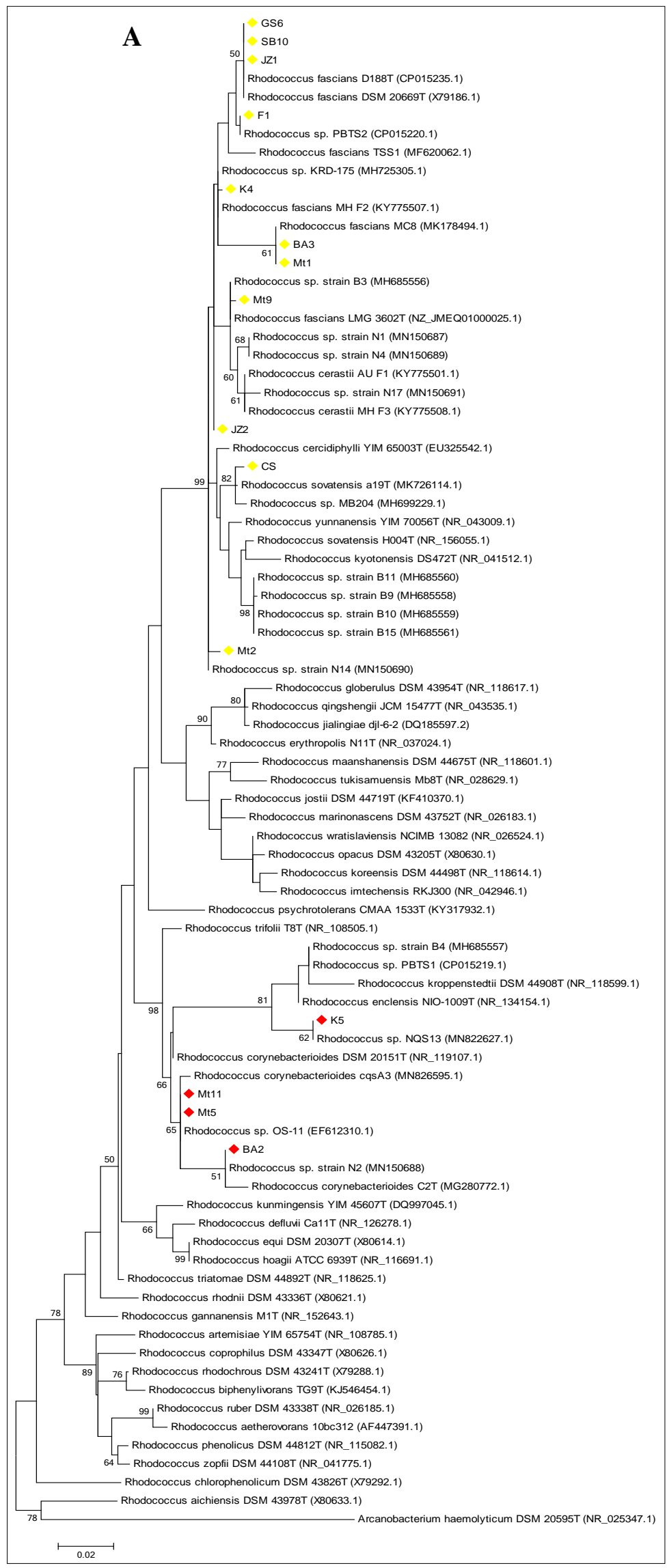

Figure 1. Cont. 


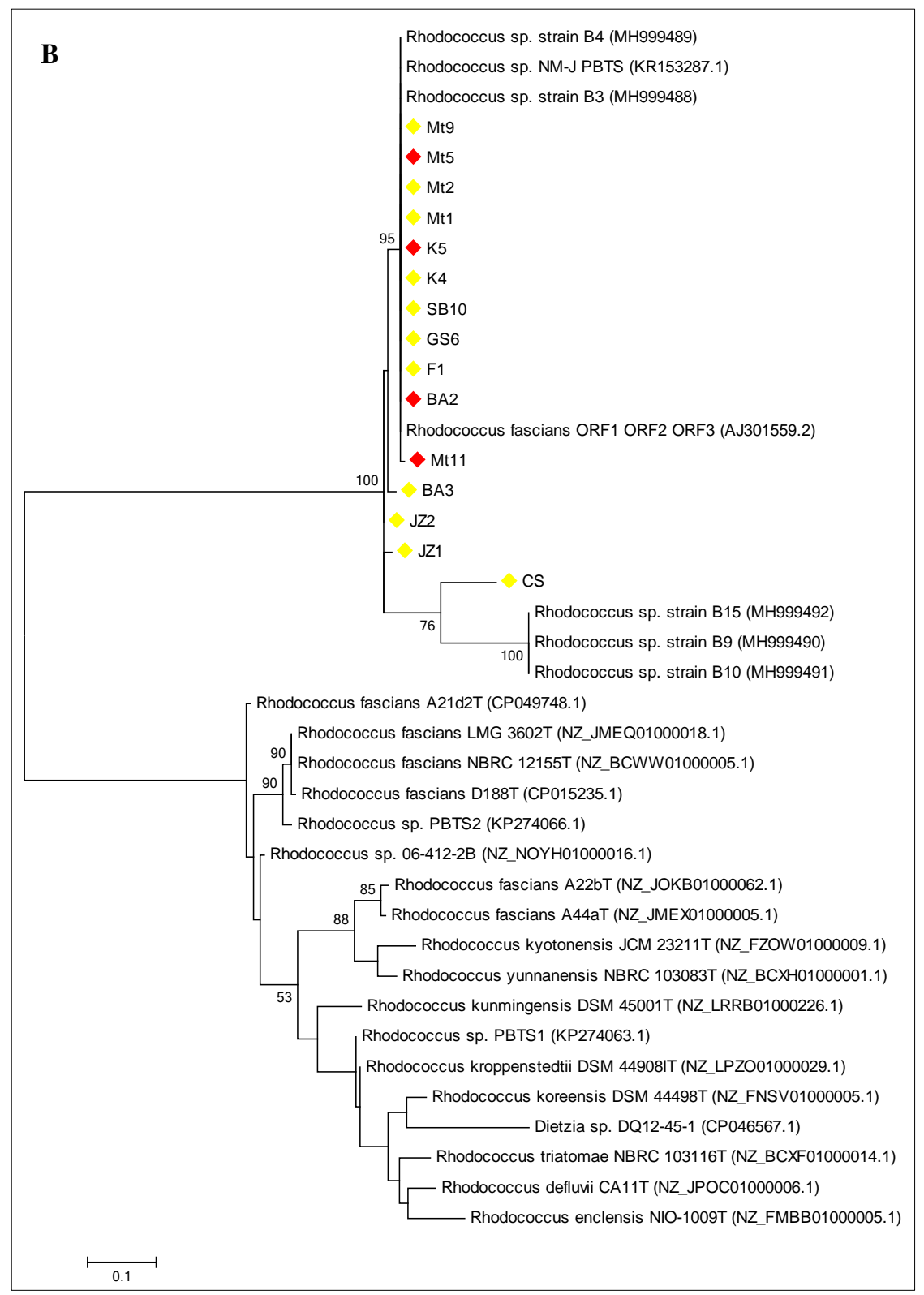

Figure 1. Phylogeny of partial 16S rRNA (A) and vicA (B) gene sequences of the fifteen Rhodococcus spp. isolates from pistachio and almond rootstocks and trees in Tunisia among different species of Rhodococcus spp. The tree was constructed using the neighbor-joining algorithm in MEGA. Nodes supported by greater than $50 \%$ of 1000 bootstrap replications are indicated. Our yellow strains are labeled by yellow dot markers and red-orange strains are labeled by red dot markers. Type strains were followed by the letter $\mathrm{T}$.

\subsection{Virulence Screening of Bacterial Strains}

\subsubsection{Virulence on Pisum Sativum}

The pathogenicity of pistachio and almond Rhodococcus strains on inoculated pea seedlings was evaluated based on stem length and total number of shoots per seedling compared to the negative control. Symptoms developed on inoculated pea seedlings in this study were also compared to those caused by Rhodococcus spp. isolates from diseased ornamentals in Tunisia $[38,39]$. Fourteen days post-inoculation, most of the pistachio and almond Rhodococcus strains caused severe growth effects to pea seedlings showing the typical multiple shoot symptom of R. fascians infection (Figure 2, Table 3). 


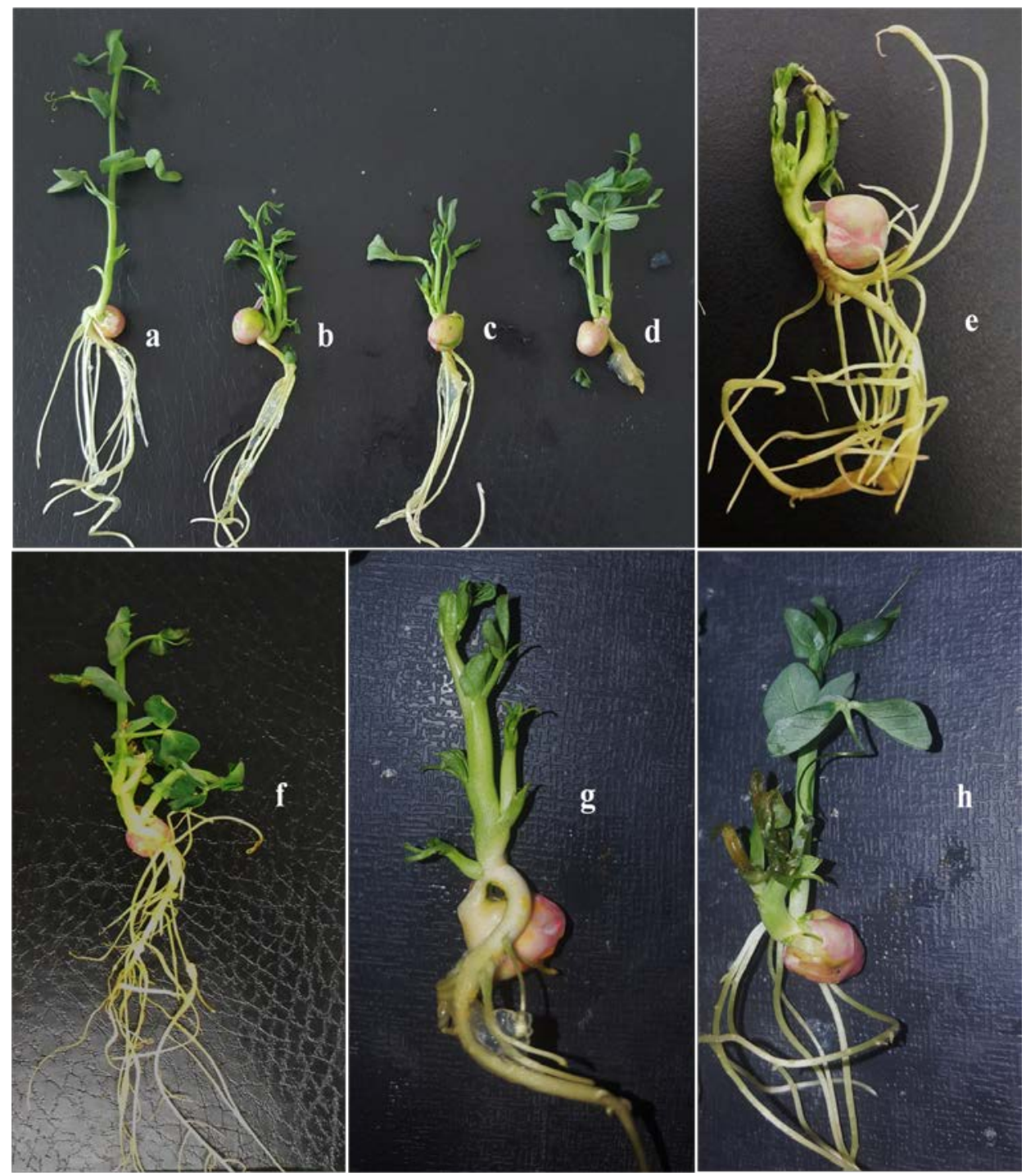

Figure 2. Phenotype of pea seedlings inoculated with pistachio and almond Rhodococcus strains 14 days post inoculation (dpi). (a) Negative control inoculated with Yeast Extract Broth. (b) and (c) Multiple shoots at cotyledon node of pea seedlings inoculated with Rhodococcus almond strains BA3 and BA2, respectively. (d) Multiple shoots and inhibited root growth of pea seedlings inoculated with Rhodococcus pistachio strain K5. (e) Leafy gall of inoculated pea seedlings with Rhodococcus almond strain GS6. (f) Multiple shoots of inoculated pea seedlings with Rhodococcus almond strain SB10. (g) Swollen stem and reduced shoot and root growth of inoculated pea seedlings with Rhodococcus pistachio strain Mt9. (h) Hypertrophied shoots of pea seedlings inoculated with Rhodococcus pistachio strain Mt11.

Symptoms on inoculated peas varied from multiple shoots developing at the cotyledon node (Figure $2 \mathrm{~b}-\mathrm{h}$ ) to root growth inhibition (Figure $2 \mathrm{~d}, \mathrm{~g}, \mathrm{~h}$ ), swollen and hypertrophied shoots (Figure $2 \mathrm{e}-\mathrm{h}$ ), and stunted shoot and leaf growth (Figure $2 \mathrm{~b}-\mathrm{h}$ ) when compared with negative control (Figure 2a). The same symptoms were observed in previous studies on pea seedlings inoculated with Rhodococcus spp. strains isolated from diseased ornamentals [38,39]. The number of shoots per seedling was significantly higher $(p \leq 0.05)$ in seedlings inoculated with Rhodococcus strains SB10, K5, Mt5, and Mt11 compared to the negative control (Table 3). Inoculation with these strains resulted in the production of over three times the number of shoots per seedling $(p \leq 0.05)$ of non-inoculated controls (Table 3). Rhodococcus strain SB10 from almond and Rhodococcus Mt11 strain from pistachio showed strong pathogenicity causing fasciations on 90 and $100 \%$ of inoculated 
pea seedlings, respectively (Table 3). Moreover, another three almond Rhodococcus strains, BA3, F1, and GS6, showed strong pathogenicity and caused up to 60 and $80 \%$ of pea height reduction $(p \leq 0.05)$ compared to non-inoculated peas (Table 3). Both epiphytic and endophytic Rhodococcus strains were recovered from inoculated pea seedlings but not from uninoculated peas. The vicA gene was successfully amplified by PCR from all of these strains, thus confirming their relatedness with abnormal growth of peas.

Table 3. Phenotypic characteristics of pea seedlings inoculated with Rhodococcus strains from almond and pistachio trees.

\begin{tabular}{|c|c|c|c|}
\hline Strain & $\begin{array}{c}\text { Fasciation } \\
\text { Symptoms }^{x}(\%)\end{array}$ & $\begin{array}{c}\text { Main Stem } \\
\text { Length }(\mathrm{mm}) \mathrm{y}\end{array}$ & $\begin{array}{c}\text { Total Number } \\
\text { of Shoots }^{z}\end{array}$ \\
\hline Control & 0 & $108.8 \mathrm{a} \pm 0.50$ & $1 \mathrm{a} \pm 0.00$ \\
\hline JZ1 & 0 & 61 bcdef \pm 0.6 & $1.0 \mathrm{a} \pm 0.0$ \\
\hline JZ2 & 0 & 73 abcdef \pm 1.0 & $1.0 \mathrm{a} \pm 0.0$ \\
\hline BA2 & 0 & 54 cdef \pm 0.7 & $1.0 \mathrm{a} \pm 0.0$ \\
\hline BA3 & 10 & 40 edfg \pm 0.7 & $1.7 \mathrm{a} \pm 0.4$ \\
\hline $\mathrm{F} 1$ & 20 & $17,1 \mathrm{~g} \pm 0.14$ & $1.3 \mathrm{a} \pm 0.21$ \\
\hline GS6 & 40 & $32.2 \mathrm{fg} \pm 0.51$ & $1.8 \mathrm{a} \pm 0.35$ \\
\hline SB10 & 90 & 38 efg \pm 0.48 & $3.3 b \pm 0.33$ \\
\hline CS & 0 & 69 abcdef \pm 1.4 & $1.0 \mathrm{a} \pm 0.0$ \\
\hline K4 & 10 & 73.3 abcde \pm 1.2 & $1.3 \mathrm{a} \pm 0.2$ \\
\hline K5 & 60 & 58 bcdef \pm 0.83 & $2.3 b \pm 0.42$ \\
\hline Mt1 & 20 & $85 \mathrm{abc} \pm 0.8$ & $1.7 \mathrm{a} \pm 0.4$ \\
\hline Mt2 & 0 & 77 abcde \pm 1.4 & $1.0 \mathrm{a} \pm 0.2$ \\
\hline Mt5 & 20 & 63 bcdef \pm 1.1 & $2.3 \mathrm{~b} \pm 0.8$ \\
\hline Mt9 & 0 & $81 \mathrm{abcd} \pm 0.8$ & $1.0 \mathrm{a} \pm 0.0$ \\
\hline Mt11 & 100 & 59 bcdef \pm 0.8 & $2.0 \mathrm{~b} \pm 0.2$ \\
\hline
\end{tabular}

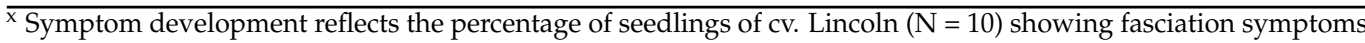
at 14 days post-inoculation. $y, z$ Means \pm standard error represent the average of plant height and total number of shoots per seedling $(\mathrm{N}=10)$. Different letters indicate a significant difference between treatments according to Student-Newman-Keuls test at $p \leq 0.05$.

\subsubsection{Fas and Att Virulence Genes Detection}

PCR amplification of the plasmid-borne virulence genes fas and att was performed using Rhodococcus strains isolated from host of origin and those recovered from inoculated pea seedlings. PCR amplifications of fas-1, fas D, and attA genes in our Rhodococcus strains consistently produced multiple PCR products of various sizes (data not shown). However, amplicons of the expected sizes of fas-1 (225 bp), fas D (195 bp), and att A (505 bp) genes were detected in most of our strains using JPEL/JPER, Fas-F/Fas-R, and attA-585F/attA-879R primers, respectively. The primers, $\mathrm{p} 450-\mathrm{F} / \mathrm{p} 450-\mathrm{R}$ designed for fas A gene amplification from pathogenic isolates D188 failed to yield a product from our strains. Additionally, the att $\mathrm{R}$ and fasR genes, predicted to encode LysR-type and AraC-type transcriptional regulators, respectively, and necessary for pathogenicity have not been detected in our strains using attR-683F/attR-887R and fas R F/fas R R primers.

After repeated attempts of PCR optimizations to detect clean PCR amplicons, the sequenced PCR fragment failed to give similar homologs to fas-1, fas D, and attA genes. However, there are seven and eight mismatches between the two primers JPEL and JPER designed to amplify the fas- 1 gene and the fas sequence in pFiD188 (Supplementary Materials File F1). In order to investigate the characteristic virulence of our strains, we have sequenced the complete genome of $R$. fascians strains GS6 and SB10 from almond and $R$. kroppenstedtii strain K5 from pistachio (Dhaouadi et al., 2020b), which showed strong 
pathogenicity effect on peas (this study). CDSs homologous to the att locus (attABCDEFGHRX genes), fasR, fas B, fas C, fasE, and fas F genes of pFiD188 were present in the genome sequences of these strains (JAAFYX000000000, JAAFYW000000000, JAAFYU000000000). The Mtr1 and Mtr2 genes encoding a SAM (S-adenosylmethionine-dependent methyltransferase) were also generated from these strains. No fas D (isopentenyl transferase) or fas A (putative p450 monooxygenase) genes, which were key virulence genes of the model strain D188 of $R$. fascians, were detected in our strains. The results of TBLASTN against the 4804 protein sequences of the chromosome of D188 and our R. fascians SB10 and GS6 assemblies showed that these two assemblies are quite closely related to D188 with $\approx 1 / 3$ of the D188 proteins having $>99 \%$ match to the genomes, which are very different from the linear plasmid results (data not shown).

\section{Discussion}

Previous studies on the occurrence of plant pathogenic Rhodococcus spp. isolates focused on ornamental plant species propagated in commercial nurseries (Dhaouadi et al. 2019 , 2020a) with no data on the prevalence of Rhodococcus spp. on permanent crops in Tunisia. The present study has shown that Rhodococcus spp. isolates are present in different regions of the country growing pistachio and almond rootstocks and trees. While most of the isolates obtained from these crops were leaf epiphytes, only GS6 and SB10 strains were endophytes of leaf almond rootstocks. One commercial nursery in Kasserine governorate propagating fruit tree rootstocks had bushy almond rootstocks with stunted shoot growth with multiple shoots and considerable compact growth. The one endophytic strain obtained from these almond rootstocks, identified as R. fascians strain GS6 [57], caused severe growth effect on peas. However, the original cause of the symptoms observed on almond rootstocks is yet to be determined.

Since the identification based on $16 \mathrm{~S}$ rDNA and vicA genes of our strains was insufficient in discriminating between species, a previous study [57] on concatenated gene sequence comparisons identified several of our strains as $R$. fascians and others as $R$. kroppenstedtii, while some remained unclassified and may represent novel species. The vicA gene has been reported to be implicated in $R$. fascians pathogenicity [35,64], but it was recently detected in red-orange Rhodococcus isolates associated with Pistachio Bushy Top Syndrome [36,37] and diseased ornamentals $[38,39]$. The vicA-based phylogenetic tree showed that our strains are separated from the plant pathogenic $R$. fascians D188 and the Rhodococcus PBTS isolates. However, many members of the Actinobacteria, including 407 Rhodococcus isolates, harbor this gene [16], and therefore, this chromosomal locus cannot be used as a phylogenetic trait in classifying plant pathogenic members of Rhodococcus neither in resolving members of this genus.

Eleven Rhodococcus strains obtained in this study showed a high degree of pathogenicity on pea seedlings. Strains related to $R$. fascians including SB10, BA3, F1, and GS6 strains were the most pathogenic, causing multiple shoots and reduced plant height and root growth of pea seedlings. Two of these strains, BA3 and F1, are epiphytic strains obtained from asymptomatic almond trees. Moreover, the red-orange Rhodococcus sp. Mt11, an epiphytic strain obtained from asymptomatic pistachio trees caused a systemic reaction in $100 \%$ of inoculated peas. Previous studies indicated that only endophytic virulent strains of $R$. fascians are capable of affecting the morphology of the plant, while epiphytic strains are nonpathogenic $[16,28,29]$. In our study, the epiphytic strains BA3, F1, and Mt11 have been established endophytically in peas and therefore are pathogenic. However, pea bioassay has been implemented for the evaluation of the pathogenicity and may not reflect what would occur on other host plants. For this matter, pathogenicity assays on pistachio and almond rootstocks are necessary.

The detection of virulence genes in our strains using published primers to target the plasmid-borne fas and att genes of $R$. fascians has been problematic, yet these strains influenced pea development. However, fasR and the 10 att genes have been found on contigs of the complete genome sequence of GS6, SB10, and K5 strains [40]. Surprisingly, 
none of the other genes on the contigs of these strains are homologous to those on pFiD188 (S, Dhaouadi, personal communication). The ability of these strains and the other epiphytic strains to invade pea seedlings and produce symptoms may be conferred by chromosomal genes [14] or models of plant pathogenic Rhodococcus virulence are different from the conserved virulence plasmid pFiD188 of $R$. fascians D188 [15,17].

Epidemiological studies and the genomic characterization of Rhodococcus isolates from different nurseries suggested that these bacteria are transmitted due to independent introductions, reservoir populations, and point source outbreaks [16]. Recent findings illustrated the presence of plant pathogenic Rhodococcus spp. in two independent commercial nurseries in Tunisia causing diseases on I. herbestii and E. japonicus plants [38,39]. Consequently, the propagation of herbaceous plants and fruit trees in the same propagation facilities may represent a risk, since plant pathogenic strains of Rhodococcus infect primarily herbaceous plants [65]. Overall, sanitation from greenhouse to field situations is paramount to the prevention of a PBTS-like outbreak on pistachio and almond in Tunisia and the Mediterranean Basin.

\section{Conclusions}

The data in this paper could be used toward the development of a phylloplane ecology study that addresses the putative risk of these bacteria to economically important crops. We have documented for the first time in Tunisia a collection of a series of Rhodococcus isolates that includes eight strains from pistachio and seven strains from almond leaves. Ecological and pathological studies on members of this Genus are valuable for mitigation of future plant disease epidemics.

Supplementary Materials: The following are available online at https:/ /www.mdpi.com/2073-4395 /11/2/355/s1, File F1: Mismatches between JPEL/JPER primers and fas sequence of $R$. fascians D188.

Author Contributions: Conceptualization, S.D., A.M.H. and A.R; methodology, S.D. and A.M.H.; software, S.D.; validation, S.D., A.M.H. and A.R.; formal analysis, S.D.; investigation, S.D. and A.M.H.; resources, A.R.; data curation, S.D. and A.M.H.; writing—original draft preparation, S.D. and A.M.H.; writing—review and editing, A.R.; visualization, A.R.; supervision, A.R.; project administration, A.R.; funding acquisition, A.R. All authors have read and agreed to the published version of the manuscript.

Funding: This research received no external funding.

Institutional Review Board Statement: Not applicable.

Informed Consent Statement: Not applicable.

Data Availability Statement: Not applicable.

Acknowledgments: The authors would like to thank several almond and pistachio growers for accepting to visit their nurseries and orchards and for generously providing samples. We thank Sophien Kamoun (The Sainsbury Laboratory) for running the compositionally adjusted substitution matrices and Gapped BLAST and PSI-BLAST programs.

Conflicts of Interest: The authors declare no conflict of interest.

\section{References}

1. Bell, K.S.; Philp, J.C.; Aw, D.W.J.; Christofi, N. The genus Rhodococcus. Appl. Microbio. 1998, 85, 195-210. [CrossRef] [PubMed]

2. Miteva, V.I.; Sheridan, P.P.; Brenchley, J.E. Phylogenetic and physiological diversity of microorganisms isolated from a deep Greenland glacier ice core. Appl. Environm. Microbiol. 2004, 70, 202-213. [CrossRef] [PubMed]

3. Máthé, I.; Borsodi, A.K.; Tóth, E.M.; Felföldi, T.; Jurecska, L.; Krett, G.; Kelemen, Z.; Elekes, E.; Barkács, K.; Márialigeti, K. Vertical physico-chemical gradients with distinct microbial communities in the hypersaline and heliothermal Lake Ursu (Sovata, Romania). Extremophiles 2014, 18, 501-514. [CrossRef] [PubMed]

4. Benedek, T.; Vajna, B.; Tancsics, A.; Marialigeti, K.; Lanyi, S.Z.; Mathe, I. Remarkable impact of PAHs and TPHs on the richness and diversity of bacterial species in surface soils exposed to long-term hydrocarbon pollution. World, J. Microbiol. Biotechnol 2013, 29, 1989-2002. [CrossRef] 
5. Táncsics, A.; Máthé, I.; Benedek, T.; Tóth, E.M.; Atasayar, E.; Spröer, C.; Márialigeti, K.; Felföldi, T.; Kriszt, B. Rhodococcus sovatensis sp. nov.; an actinomycete isolated from the hypersaline and heliothermal Lake Ursu. Int. J. Syst. Evol. Microbiol. 2017, 67, 190-196.

6. Silva, L.J.; Souza, D.T.; Genuario, D.B.; Hoyos, H.A.V.; Santos, S.N.; Rosa, L.H.; Zucchi, T.D.; Melo, I.S. Rhodococcus psychrotolerans sp. nov.; isolated from rhizosphere of Deschampsia antarctica. Antonie Van Leeuwenhoek 2017, 111, 629-636. [CrossRef]

7. Kämpfer, P.; Wellner, S.; Lohse, K.; Lodders, N.; Martin, K. Rhodococcus cerastii sp. nov. and Rhodococcus trifolii sp. nov.; two novel species isolated from leaf surfaces. Int. J. Syst. Evol. Microbiol. 2013, 63, 1024-1029. [CrossRef]

8. Traw, M.B.; Kniskern, J.M.; Bergelson, J. SAR increases fitness of Arabidopsis thaliana in the presence of natural bacterial populations. Evolution 2007, 61, 2444-2449. [CrossRef]

9. Li, J.; Zhao, G.Z.; Chen, H.H.; Qin, S.; Xu, L.H.; Jiang, C.L.; Li, W.J. Rhodococcus cercidiphylli sp. nov.; a new endophytic actinobacterium isolated from a Cercidiphyllum japonicum leaf. Syst. Appl. Microbiol. 2008, 31, 108-113. [CrossRef]

10. Achari, G.A.; Ramesh, R. Diversity, biocontrol, and plant growth promoting abilities of xylem residing bacteria from solanaceous crops. Int. J. Microbiol. 2014, 296521. [CrossRef]

11. Belimoy, A.A.; Safronova, V.I.; Sergeyeva, T.A.; Egorova, T.N.; Matveyeva, V.A.; Tsyganov, V.E.; Borisov, A.Y.; Tikhonovich, I.A.; Kluge, C.; Preisfeld, A.; et al. Characterization of plant growth promoting rhizobacteria isolated from polluted soils and containing 1-aminocyclopropane-1-carboxylate deaminase. Can. J. Microbio. 2001, 47, 642-652. [CrossRef] [PubMed]

12. Tsavkelova, E.A.; Cherdyntseva, T.A.; Lobakova, E.S.; Kolomeitseva, G.L.; Netrusov, A.I. Microbiota of the orchid rhizoplane. Microbiology 2001, 70, 492-497. [CrossRef]

13. Cohen, M.F.; Yamasaki, H. Involvement of nitric oxide synthase in sucrose-enhanced hydrogen peroxide tolerance of Rhodococcus sp. strain APG1, a plant-colonizing bacterium. Nitric Oxide 2003, 9, 1-9. [CrossRef]

14. Francis, I.M.; Stes, E.; Zhang, Y.; Rangel, D.; Audenaert, K.; Vereecke, D. Mining the genome of Rhodococcus fascians, a plant growth-promoting bacterium gone astray. New Biotechnol. 2016, 33, 706-717. [CrossRef] [PubMed]

15. Creason, A.L.; Vandeputte, O.M.; Savory, E.A.; Davis, E.W., II; Putnam, M.L.; Hu, E.; Swader-Hines, D.; Mol, A.; Baucher, M.; Prinsen, E.; et al. Analysis of genome sequences from plant pathogenic Rhodococcus reveals genetic novelties in virulence loci. PLoS ONE 2014, 9, e101996. [CrossRef] [PubMed]

16. Savory, E.A.; Fuller, S.L.; Weisberg, A.J.; Thomas, W.J.; Gordon, M.I.; Stevens, D.M.; Creason, A.L.; Belcher, M.S.; Serdani, M.; Wiseman, M.S.; et al. Evolutionary transitions between beneficial and phytopathogenic Rhodococcus challenge disease management. eLife 2017, 6, e30925. [CrossRef]

17. Savory, E.; Weisberg, A.J.; Stevens, D.M.; Creason, A.L.; Fuller, S.L.; Pearce, E.M.; Chang, J.H. Phytopathogenic Rhodococcus Have Diverse Plasmids with few conserved virulence functions. Front. Microbiol. 2020, 11, 1022. [CrossRef]

18. Francis, I.M.; Vereecke, D. Plant-Associated Rhodococcus Species, for Better and for Worse. In Biology of Rhodococcus; Alvarez, H., Ed.; Microbiology Monographs; Springer: Berlin/Heidelberg, Germany, 2019; Volume 16, pp. 359-377.

19. Dhaouadi, S.; Mougou, A.H.; Rhouma, A. The plant pathogen Rhodococcus fascians. History, disease symptomatology, host range, pathogenesis and plant-pathogen interaction. Ann. Appl. Biol. 2020, 177, 4-15. [CrossRef]

20. Cornelis, K.; Ritsema, T.; Nijsse, J.; Holsters, M.; Goethals, K.; Jaziri, M. The plant pathogen Rhodococcus fascians colonizes the exterior and interior of the aerial parts of plants. Mol. Plant Microbe Interact. 2001, 14, 599-608. [CrossRef]

21. Goethals, K.; Vereecke, D.; Jaziri, M.; Van Montagu, M.; Holsters, M. Leafy gall formation by Rhodococcus fascians. Annu. Rev. Phytopatho. 2001, 39, 27-52. [CrossRef]

22. Stes, E.; Francis, I.; Pertry, I.; Dolzblasz, A.; Depuydt, S.; Vereecke, D. The leafy gall syndrome induced by Rhodococcus fascians. FEMS Microbiol. Lett. 2013, 342, 187-194. [CrossRef] [PubMed]

23. Dolzblasz, A.; Banasiak, A.; Vereecke, D. Neovascularization during leafy gall formation on Arabidopsis thaliana upon Rhodococcus fascians infection. Planta 2018, 247, 215-228. [CrossRef] [PubMed]

24. Pertry, I.; Václavíková, K.; Depuydt, S.; Galuszka, P.; Spíchal, L.; Temmerman, W.; Stes, E.; Schmülling, T.; Kakimoto, T.; Van Montagu, M.; et al. Identification of Rhodococcus fascians cytokinins and their modus operandi to reshape the plant. Proc. Natl. Acad. Sci. USA 2009, 106, 929-934. [CrossRef]

25. Pertry, I.; Václavíková, K.; Gemrotová, M.; Spíchal, L.; Galuszka, P.; Depuydt, S.; Temmerman, W.; Stes, E.; De Keyser, A.; Riefler, M.; et al. Rhodococcus fascians impacts plant development through the dynamic Fas-mediated production of a cytokinin mix. Mol. Plant Microbe Interact. 2010, 23, 1164-1174. [CrossRef]

26. Francis, I.M.; De Keyser, A.; De Backer, P.; Simón-Mateo, C.; Kalkus, J.; Pertry, I.; Ardiles-Diaz, W.; De Rycke, R.; Vandeputte, O.M.; El Jaziri, M.; et al. pFiD188, the linear virulence plasmid of Rhodococcus fascians D188. Mol. Plant Microbe Int. 2012, 25, 637-647. [CrossRef]

27. Radhika, V.; Ueda, N.; Tsuboi, Y.; Kojima, M.; Kikuchi, J.; Kudo, T.; Sakakibara, H. Methylated cytokinins from the phytopathogen Rhodococcus fascians mimic plant hormone activity. Plant Physiol. 2015, 169, 1118-1126. [CrossRef]

28. Dhandapani, P.; Song, J.; Novak, O.; Jameson, P.E. Infection by Rhodococcus fascians maintains cotyledons as a sink tissue for the pathogen. Ann. Bot. 2017, 119, 841-852.

29. Dhandapani, P.; Song, J.; Novák, O.; Jameson, P.E. Both epiphytic and endophytic strains of Rhodococcus fascians influence transporter gene expression and cytokinins in infected Pisum sativum L. seedlings. Plant Growth Regul. 2018, 85, $231-242$. [CrossRef] 
30. Jameson, P.E.; Dhandapani, P.; Song, J.; Zatloukal, M.; Strnad, M.; Remus-Emsermann, M.N.P.; Schlechter, R.O.; Novák, O. The cytokinin complex associated with Rhodococcus fascians: Which compounds are critical for virulence? Front. Plant Sci. 2019, 10, 674. [CrossRef] [PubMed]

31. Temmerman, W.; Vereecke, D.; Dreesen, R.; Van Montagu, M.; Holsters, M.; Goethals, K. Leafy gall formation is controlled by fasR, an AraC-type regulatory gene in Rhodococcus fascians. Bacteriology 2000, 182, 5832-5840. [CrossRef]

32. Crespi, M.; Messens, E.; Caplan, A.B.; van Montagu, M.; Desomer, J. Fasciation induction by the phytopathogen Rhodococcus fascians depends upon a linear plasmid encoding a cytokinin synthase gene. EMBO J. 1992, 11, 795-804. [CrossRef]

33. Vereecke, D.; Zhang, Y.; Francis, I.M.; Lambert, P.Q.; Venneman, J.; Stamler, R.A.; Kilcrease, J.; Randall, J.J. Functional genomics insights into the pathogenicity, habitat fitness, and mechanisms modifying plant development of Rhodococcus sp. PBTS1 and PBTS2. Front. Microbiol. 2020, 11, 14. [CrossRef]

34. Maes, T.; Vereecke, D.; Ritsema, T.; Cornelis, K.; Ngo Thi Thu, H.; Van Montagu, M.; Holsters, M.; Goethals, K. The att locus of Rhodococcus fascians strain D188 is essential for full virulence on tobacco through the production of an autoregulatory compound. Mol. Microbiol. 2001, 42, 13-28. [CrossRef]

35. Nikolaeva, E.V.; Park, S.Y.; Kang, S.; Olson, T.N.; Kim, S.H. Ratios of cells with and without virulence genes in Rhodococcus fascians populations correlate with degrees of symptom development. Plant Dis. 2009, 93, 499-506. [CrossRef]

36. Stamler, R.A.; Kilcrease, J.; Kallsen, C.; Fichtner, E.J.; Cooke, P.; Heerema, R.J.; Randall, J.J. First Report of Rhodococcus isolates causing pistachio bushy top syndrome on 'UCB-1' rootstock in California and Arizona. Plant Dis. 2015, 99, 1468-1476. [CrossRef]

37. Stamler, R.A.; Heerema, R.; Randall, J.J. First report of Phytopathogenic Rhodococcus isolates on pistachio bushy top syndrome 'UCB-1' rootstock in New Mexico. Plant Dis. 2015, 99, 1854. [CrossRef]

38. Dhaouadi, S.; Mougou, A.H.; Bahri, B.A.; Rhouma, A.; Fichtner, E.J. First report of Rhodococcus spp. isolates causing stunting and lateral stem proliferation of Iresine herbstii 'Aureo-Reticulata' in Tunisia. Phytopathol. Mediterr. 2019, 58, 391-394.

39. Dhaouadi, S.; Mougou, A.H.; Gleason, M.L.; Rhouma, A.; Fichtner, E.J. First report of bushy stunt of Japanese spindle caused by Rhodococcus spp. in Tunisia. Plant Dis. 2020, 104, 1250. [CrossRef]

40. Dhaouadi, S.; Win, J.; Mougou, A.H.; Harant, A.; Kamoun, S.; Rhouma, A. Genome sequences of plant-associated Rhodococcus sp. isolates from Tunisia. Microbiol. Resour. Announc. 2020, 9, e00293-20. [CrossRef]

41. California Department of Food and Agriculture. Fruit and nut crops. In California Agricultural Statistics Review; 2013-2014; pp. 56-80. Available online: https://www.motherjones.com/wp-content/uploads/resourcedirectory_2013-2014_1.pdf (accessed on 5 January 2021).

42. International Nut and Dried Fruit Council. Statistics Database; PR Newswire: New York, NY, USA, 2018.

43. Gouta, H.; Ksia, E.; Ayachi, M.M.; Martínez-Gómez, P. Agronomical evaluation of local Tunisian almond cultivars and their breeding prospects. Eur. J. Hortic. Sci. 2019, 84, 73-84. [CrossRef]

44. Ghrab, M.; Ben Mimoun, M.; Gouta, H. Pistachio production in Tunisia. FAO CIHEAM Nucis-Newsletter 2004, $12,19-21$.

45. Gouta, H.; Mars, M.; Gouiaa, M.; Ghrab, M.; Zarrouk, M.; Mliki, A. Genetic diversity of almond (Prunus amygdalus batsch) in Tunisia: A morphological traits analysis. Acta Hortic. 2011, 912, 351-358. [CrossRef]

46. Ghrab, M.; Zribi, F.; Chelli-Chaabouni, A.; Gouta, H.; Ben Mimoun, M. Genetic diversity of Pistachio in Tunisia. Options Méditerranéennes Série A Séminaires Méditerranéens 2010, 94, 221-228.

47. Michailides, T.J.; Morgan, D.P.; Doster, M.A.; Kölliker, R. Biology, Epidemiology and Control of Alternaria and Aspergillus Bligths of Pistachio and Effects of These Diseases on Nut Quality; Annual Reports Crop; California Pistachio Industry, $1994 ;$ pp. 49-56.

48. Michailides, T.J. Foliar and Fruit Fungal Diseases of Pistachio. In Advanced Course Production and Economics of Nut Crops; 1998; pp. 18-29.

49. Michailides, T.J. Panicle and shoot blight. Compendium of Nut Crop Diseases in Temperate Zones; Teviotdale, B.L., Michailides, T.J., Pscheidt, J.W., Eds.; American Phytopathological Society: St. Paul, MN, USA, 2002; pp. 68-69.

50. Guldur, M.E.; Dikilitas, M.; Ak, B.E. Pistachio diseases in the southeastern Anatolian region. Acta Hortic. 2011, 912, 739-742. [CrossRef]

51. Vereecke, D.; Fichtner, E.J.; Lambert, P.Q.; Cooke, P.; Kilcrease, J.; Stamler, R.; Zhang, Y.; Francis, I.M.; Randall, J.J. Colonization and survival capacities underlying the multi-faceted life of Rhodococcus sp. PBTS1 and PBTS2. Plant Pathol. 2020. [CrossRef]

52. Kado, C.I.; Heskett, M.G. Selective media for isolation of Agrobacterium, Corynebacterium, Erwinia, Pseudomonas, and Xanthomonas. Phytopathology 1970, 60, 969-976. [CrossRef]

53. Pei, Z.; Bini, E.J.; Yang, L.; Zhou, M.; Francois, F.; Blaser, M.J. Bacterial biota in the human distal esophagus. PNAS 2004, 101, 4250-4255. [CrossRef]

54. Nikolaeva, E.V.; Kang, S.; Olson, T.N.; Kim, S.H. Real-time PCR detection of Rhodococcus fascians and discovery of new plants associated with R. fascians in Pennsylvania. Plant Health Prog. 2012, 13, 24. [CrossRef]

55. Stange, R.R.; Jeffares, D.; Young, C.; Scott, D.B.; Eason, J.R.; Jameson, P.E. PCR amplification of the fas -1 gene for the detection of virulent strains of Rhodococcus fascians. Plant Pathol. 1996, 45, 407-417. [CrossRef]

56. Serdani, M.; Curtis, M.; Miller, M.L.; Kraus, J.; Putnam, M.L. Loop-mediated isothermal amplification and polymerase chain reaction methods for specific and rapid detection of Rhodococcus fascians. Plant Dis. 2013, 97, 517-529. [CrossRef]

57. Dhaouadi, S.; Mougou, A.H.; Wu, C.J.; Gleason, M.L.; Rhouma, A. Sequence analysis of 16S rDNA, gyrB and alkB genes of plant-associated Rhodococcus species from Tunisia. Int. J. Syst. Evol. Microbio. 2020. [CrossRef] [PubMed] 
58. Altschul, S.F.; John, C.; Wootton, E.; Gertz, M.; Agarwala, R.; Morgulis, A.; Schaffer, A.A.; Yi-Kuo, Y. Protein database searches using compositionally adjusted substitution matrices. FEBS J. 2005, 272, 5101-5109. [CrossRef]

59. Altschul, S.F.; Thomas, L.; Madden, A.A.; Zhang, S.J.; Zhang, Z.; Miller, W.; Lipman, D.J. Gapped BLAST and PSI-BLAST: A new generation of protein database search programs. Nucleic Acids Res. 1997, 25, 3389-3402. [CrossRef] [PubMed]

60. Tamura, K.; Stecher, G.; Peterson, D.; Filipski, A.; Kumar, S. MEGA6: Molecular Evolutionary Genetics Analysis version 6.0. Mol. Biol. Evol. 2013, 30, 2725-2729. [CrossRef] [PubMed]

61. Tamura, K.; Nei, M. Estimation of the number of nucleotide substitutions in the control region of mitochondrial DNA in humans and chimpanzees. Mol. Biol. Evol. 1993, 10, 512-526. [PubMed]

62. Stamatakis, A. Maximum likelihood-based phylogenetic analyses with thousands of taxa and mixed models. Bioinformatics 2006, 22, 2688-2690. [CrossRef]

63. Biesta-Peters, E.G.; Reij, G.M.; Joosten, H.; Gorris, L.G.M.; Marcel, H.; Zwietering, M.H. Comparison of two optical-density-based methods and a plate count method for estimation of growth parameters of Bacillus cereus. Appl. Environ. Microbiol. 2010, 76, 1399-1405. [CrossRef]

64. Vereecke, D.; Cornelis, K.; Temmerman, W.; Jaziri, M.; Van Montagu, M.; Holsters, M.; Goethals, K. Chromosomal locus that affects pathogenicity of Rhodococcus fascians. Bacteriology 2002, 184, 1112-1120. [CrossRef]

65. Putnam, M.L.; Miller, M.L. Rhodococcus fascians in herbaceous perennials. Plant Dis. 2007, 91, 1064-1076. [CrossRef] 